\title{
The Arabic Hyperbolic Pattern 'Fa??al' in Two Recent Translations of the Qur'an
}

\author{
Amr M. El-Zawawy (Corresponding author) \\ Department of English, Faculty of Education, Alexandria University \\ E-mail: amrzuave@yahoo.com
}

Doi:10.7575/aiac.alls.v.5n.3p.211

Received: $12 / 04 / 2014$

URL: http://dx.doi.org/10.7575/aiac.alls.v.5n.3p.211

Accepted: 28/05/2014

\begin{abstract}
The present study addresses the problem of rendering the فعال'fa??al' hyperbolic pattern into English in two recent translations of the Qur'an. Due to the variety of Qur'an translations and the large amount of hyperbolic forms of Arabic verbs recorded in the Qur'an, only two translations of the Qur'an are consulted and analyzed: these two translations, namely Saheeh International Translation (1997) and Prof. Abdel-Haleem's (2004), are distinguished by the fact that they are recent and well-received. Moreover, the investigation of hyperbolic forms is confined to the Arabic form 'fa??al'. The study reveals that the Saheeh translator has applied morphological shifting in many examples while AbdelHaleem's translation exhibits a considerable amount of syntactic transposition, coupled with paraphrasing. The test of accuracy as administered here is to give a clear picture of the need to pay particular attention to hyperboles of the form examined and other ones not analyzed here for limitations of space.
\end{abstract}

Keywords: hyperbole, Qur'an, Qur'an translation, translation into English, Saheeh translation, Abdel-Haleem's translation, translation strategies, Arabic rhetoric

\section{Introduction}

Hyperbole, otherwise known as exaggeration or overstatement, is regarded as one of the rhetorical devices employed by language users to add extra meaning or to amplify a certain action or quality. It is also a type of "creative intensifications for evaluative or affective purposes" (Mora, 2009). Hyperbolic expressions thus act as a trope that leaves a certain impression or goes beyond the truth of a particular quality (Dung, 2010).

Despite its central role as a rhetorical device that adds purported semantic content, hyperbole has received little attention (as will be elaborated below). It is also used differently across languages, especially English and Arabic. While English regards it as a figure of speech or trope that might not covey the truth, Arabic considers it a morphological process that adds significant semantic content by emphasizing repetition of action, superhuman qualities or even professional occupation. This marked difference is better seen through the lens of translation, especially the study of the differences in the rendition of hyperbolic forms in the Qur'an into English.

Due to the variety of Qur'an translations and the large amount of hyperbolic forms of Arabic verbs recorded in the Qur'an, only two translations of the Qur'an will be consulted and analyzed: these two translations, namely Saheeh International Translation (1997) and Prof. Abdel-Haleem's (2004), are distinguished by the fact that they are recent and well-received. Moreover, the investigation of hyperbolic forms will be confined to the Arabic form فعال 'fa??al', which is the most frequent in the holy book (cf. Saleh, 2005).

The present study will thus focus on the occurrences of this form in the Qur'an as a means to examine how the two translations address the problem of the strategies involved in rendering it from Arabic into English.

\section{Studies on Hyperbole in English and Arabic}

\subsection{Studies on Hyperbole in English}

The topic of hyperbole in English has received some attention due to its recurrence in daily newspapers and conversations. One of the earliest studies is van Dijk's (1995). As a critical discourse analyst, he set out to investigate the use of hyperboles in a collection of expressions used by right-wing British newspapers and speeches delivered in the Spanish Parliament. Van Dijk discovered that hyperboles play a prominent role in the formulation of opinions, especially the effect of semantic polarization, which is highly dependent on hyperbolized forms.

Another important study is Drew and Holt's (1998). They analyzed a huge corpus of telephone conversations for a British family over a period of three years. They found out that hyperboles figured out as a recurrent rhetorical device for purposes of persuasion.

Similarly, Gibbs (2000) examined sixty-two 10-minute conversations between college students and their friends. His findings pointed to the fact that $74 \%$ of the hyperboles were viewed as humorous by a $t$ least one of the conversational participants. 
An oft-quoted study is McCarthy and Carter's (2004). They used corpus extracts from concordances generated for key lexical items for prominent semantic fields (e.g. time and number) to illustrate how hyperbolic expressions are used in context. McCarthy and Carter attempted to pinpoint the degree of an item's hyperbole-proneness, using five basic categories according to the CANCODE method:

1- Expressions of number (millions of, hundreds of, etc.),

2- Words referring to large amounts/quantities (masses of, loads of, etc.),

3- Adjective modification of amount(s) and number(s) (adjective + amounts of, etc.),

4- Time expressions (years, weeks, hours, etc.), and

5- Size, degree and intensity (enormous, endless, gigantic, etc.).

They found that shifts in footing indicated by discourse markers or narrative shift markers (e.g. time adverbs) were common within the linguistic environment of hyperboles. McCarthy and Carter's study concludes that an interactive approach to hyperbole is sine qua non for its proper understanding.

Mora (2004) explored the role of conversational interactivity in hyperbole construction and comprehension. To do so, she developed a collaborative framework, involving both speaker and listener, in order to reveal that listener response is crucial in understanding the nature of hyperboles. She compiled a corpus of naturally occurring spoken conversations, chosen at random from the British National Corpus. The responses included back channels, relevant next contributions, shifts in topic, refusals to acknowledge the speaker's overstatement. She found that relevant next contribution and back channel responses (e.g. yeah, mm, oh, etc.) were the most recurrent pattern of listeners' responses to hyperbole, which indicates understanding of the speakers' overstatement.

Sert (2008) built on the framework provided by McCarthy and Carter (2004) and Mora (2004) in order to analyze hyperboles in a British TV series called Coupling (approximately a 90,000 word corpus), and investigate their potential application in EFL classes. He attempted to answer the following questions:

1- Items within the five categories of hyperboles exist frequently in the Coupling corpus.

2- What are the similarities between CANCODE and the Coupling corpus in terms of the hyperbole-proneness of key lexical items?

3- How do speakers and listeners communicate hyperboles considering shifts in footing?

4- In what ways can a corpus analysis of hyperboles in a TV series be conducive to foreign language learning?

He found out that the discourse of TV series, unlike naturally occurring language, requires a three-channel model in analyzing the humorous effect of hyperbole. Listener responses should also be analyzed. Despite these limitations, it is believed that in countries where English is taught and spoken as a foreign language, TV series like Coupling may be used to provide comprehensible language input for L2 learners.

In a more recent study, Dung (2011) compared the use of hyperboles in 1000 samples of English and Vietnamese sources. He analyzes the data syntactically, semantically and pragmatically.

\subsection{Studies on Hyperbole in Arabic}

Although little has been written on hyperbole in Arabic, relevant studies date back to the early works of Abu Hilal al'Askari, author of al-Furooq al-Lughawiyyah, in the fourth Hegira century and Al-Rommani (d. 384 AH). Al-'Askari maintained that it is impossible for two different words in Arabic to have exactly the same meaning, especially the different hyperbolic forms. He prefers to define hyperbole as the exaggeration in meaning by going to its utmost. AlRommani, on the other hand, defines hyperbole as the denotative exaggerated meaning for the purposes of clarifying it.

Ibn Genie, in his treatise Al-Khasa'is, and Al-Zamakhshari also touch upon the same topic. Ibn Genie views hyperbole as a sub-type of ontomasia, though he distinguishes it as conveying the sense of completeness. AlZamakhshari likewise considers hyperbole and digression inseparable, but preserves the meaning of 'reaching the pinnacle' for hyperbole.

A more recent approach is Saleh's (2005). His MA thesis focuses on the use of hyperbolized forms in the Qur'an. He provides semantic and syntactic discussions of all these forms, showing that they are mainly derived from the active participle. What is significant about his research is that he gives a precise definition of each of the hyperbolized forms cited, based on exegetical accounts.

\section{Studies on Hyperbole in the Qur'an}

Studies on hyperbole in the Qur'an seem to be fragmented and shallow. To the best of the researcher's knowledge, the only comprehensive study in Arabic is Saleh's (2005) mentioned in the previous section. Other studies on the translation of hyperbole into English are just rudimentary and no more than personal thoughts.

The website Arabic Gems (January, 2007) provides a brief discussion under siyagh al mubaalaghah ('forms of intensification/hyperbolic forms'). It says that such forms denote different levels of intensity. Thus, a liar ' $k a a d h i b$ ' كاذب كذوب كذاب or a kadhdhaab also be known as a kadhoob. 
Another study is Amjad's (2013), which focuses on divine names only. He examines Qur'an translations done by three professional translators namely, Shakir (1985), Qarai (2003), and Nikayin (2006) who provided their translations in prose, phrase-by-phrase, and poetry forms respectively. He finds out that Shakir and Qarai used nearsynonymy' and 'expansion' respectively. Nikayin, however, used these two strategies almost to an equal extent as his most frequent strategies.

\section{Corpus and Methodology}

\subsection{Why these Two Translations}

The two translations selected are Saheeh International Translation (1997) and Prof. Abdel-Haleem's (2004). The reasons behind their selection are threefold. First, they are both recent, Saheeh International Publishing House Translation being published in 1997, while Prof. Abdel-Haleem's being published in 2004. Second, Saheeh International Translation (1997) was done by a native speaker, namely Umm Muhammad who is an American who converted to Islam while following an intensive study of Arabic in Syria. The editors of the Publishing House are also native speakers of English: Amatullah J. Bantley (director) and Mary M. Kennedyi. Third, Prof. Abdel-Haleem's translation is done by a specialist in both Arabic and English: he is an academic at SOAS, London University. Since its publication, his translation has been met with satisfaction, especially by Mohammed (2005, p.3), who comments that '[t]he preciseness of English is certainly commendable'. Shah (nd) also praises the translation, which is the fruit of working for seven years.

\subsection{Corpus}

Due to the numerous instances of Arabic hyperbolic forms in the Qur'an, only the occurrences of the form (i.e. fa??al) is the focus of investigation here. It occurs in 88 instances throughout the Qur'an.

\subsection{Methods}

The method adopted in the analysis of the instances quoted in the present study is to classify the occurrences according to the strategies employed in translating them by the two translators. These strategies have been largely classified into flattening, partial flattening, and conveying complete sense. Flattening refers to the loss of the meaning of the fa??al form due to adopting, for example, an active participle one. Partial flattening, however, is the attempt at conveying some parts of the semantic content of the hyperbolic form by means of syntax or otherwise. Conveying complete sense refers to the success on the part of the translator to render the hyperbolic form accurately, using any transposition or compensation. Flattening is, for short, referred to as 'flat', partial flattening as 'partial' and complete sense as 'comp'. Moreover, the Saheeh Translation is referred to for short as Sah., while the Abdel-Haleem's translation is referred to as Ah. The nine possibilities resulting from this classification are as follows:

1. Flat (Sah.), Flat (Ah)

2. Flat (Sah), Comp (Ah)

3. Flat (Sah), Partial (Ah)

4. Comp (Sah), Comp (Ah)

5. Comp (Sah), Flat (Ah)

6. Comp (Sah), Partial (Ah)

7. Partial (Sah), Partial (Ah)

8. Partial (Sah), Comp (Ah)

9. Partial (Sah), Flat (Ah)

Each instance of the hyperbolic form is provided in Arabic and English, and its Arabic Qur'anic context, followed by the two translations in question. The Arabic forms discussed are ordered alphabetically.

\section{Analysis of the Corpus}

\subsection{Flat (Sah.), Flat (Ah)}

Awwah : أواه

This hyperbolic form occurs in verse 114 of Surah Al-Tawbah as follows:

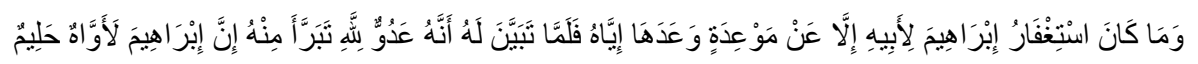

The two translations are as follows:

\section{Sah}

And the request of forgiveness of Abraham for his father was only because of a promise he had made to him. But when it became apparent to him [i.e., Abraham] that he [i.e., the

\section{$\mathrm{Ah}$}

Abraham asked forgiveness for his father because he had made a promise to him, but once he realized that his father was an enemy of God, he washed his hands of him. Abraham was tender-hearted and forbearing. 
father] was an enemy to Allah, he disassociated himself from him. Indeed was Abraham compassionate and patient.

It is clear that two translators flatten the hyperbolic form 'awwah' by opting for 'compassionate' and 'tender-hearted', respectively. The adjective chosen by the Saheeh translator is more akin to 'raheem' than 'awwah'. Taj Al-Aroos Arabic Dictionary equates 'awwah' with the meaning of someone who is expectant of an answer to his or her request from God. Moreover, as the Random House Webster's Unabridged Dictionary states, 'compassionate' is preserved for someone who shows 'compassion', the quality of showing sympathy towards another person. Similarly, 'tenderhearted' denotes sympathy. The basic distinction implied by the hyperbolic form, that is repetition and abundance, is furthermore forfeited. A better translation would have been the paraphrase 'always expectant of answer'.

Al-Sayyarah السيارة:

This hyperbolic form occurs in verse 96 of Surah Al-Ma'idah as follows:

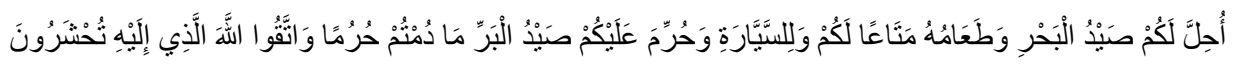

The two translations are as follows:

\section{Sah}

Lawful to you is game from the sea and its food as provision for you and the travelers, but forbidden to you is game from the land as long as you are in the state of Ihram. And fear Allah to whom you will be gathered.
$\mathrm{Ah}$

It is permitted for you to catch and eat seafood- an enjoyment for you and the traveller- but hunting game is forbidden while you are in the state of consecration [for pilgrimage]. Be mindful of God to whom you will be gathered.

Both translators ignore the implied meaning of repetition due to toil in 'al-sayyarh' (cf. Saleh, 2005). The two translators opt for a morphological solution by adding the morph '-er'. Although this morph denotes 'doing an action', it has the meaning of occupation. However, this is actually not the meaning intended. A better solution would have been 'wearied traveling caravans'.

Banna' بناء:

This hyperbolic form occurs in verse 37 of Surah $\underline{S} a d$ as follows:

$$
\text { وَالثََّّاطِينَ كُلَّ بَنَّاءِ وَغَوَّاصِ }
$$

The two translations are as follows:

$$
\begin{array}{c|c}
\text { Sah } & \text { Ah } \\
\text { And [also] the devils [of jinn] - every builder } \\
\text { and diver }
\end{array} \mid \text { and the jinn - every kind of builder and diver }
$$

The same problem recurs, but this time, the Arabic semantic atom of hyperbolizing a verb to denote occupation due to the implied meaning of repetition is lost. The two translators almost concur. The use of '-er' denotes occupation or profession in English, but the reason for hyperbolization (i.e. repetition) is forfeited. A better translation would have been 'habitual builder'.

\section{جبار Jabbar:}

This hyperbolic form occurs in verse 23 of Surah Al- $\underline{H} a s h r$ as follows:

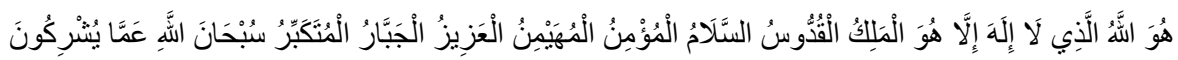


Sah

$\mathrm{He}$ is Allah, other than whom there is no deity, the Sovereign, the Pure, the Perfection, the Bestower of Faith, the Overseer, the Exalted in Might, the Compeller, the Superior. Exalted is Allah above whatever they associate with Him.

\section{$\mathrm{Ah}$}

He is God: there is no god other than Him, the Controller, the Holy One, Source of Peace, Granter of Security, Guardian over all, the Almighty, the Compeller, the Truly Great; God is far above anything they consider to be His partner

The morphological strategy is again preferred. The two translators rely on the standard translation of the divine attribute 'jabbar' without researching into its meaning. The use of '-er' here only denotes 'the agent', i.e. the doer of the action, while the repetition and abundance are lost. Moreover, the Arabic root 'j-b-r' includes the meaning of 'mending something', (see Saleh, 2005) which has not been accommodated by the two translations. A better solution would have been 'the Mender and Compeller'.

Yet they opt for 'tyrant' in other contexts where the divine attribute is not intended. Consider the following examples in verses 15, 59, 130, 19, and 35 in Surahs Ibrahim, Hud, Al-Shu?ara', Al-Qas as , and Ghafir, respectively:

$$
\text { وَاسْتَفْنَحُو اوخَابَ كُلُْ حَبَّارٍ عَنيدٍ }
$$

\section{Sah}

And they requested decision [i.e., victory from Allah], and disappointed, [therefore], was every obstinate tyrant.

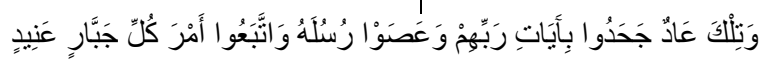

\section{Sah}

And that was Aad, who rejected the signs of their Lord and disobeyed His messengers and followed the order of every obstinate tyrant.

\section{$\mathrm{Ah}$}

They asked God to decide, and every obstinate tyrant failed-

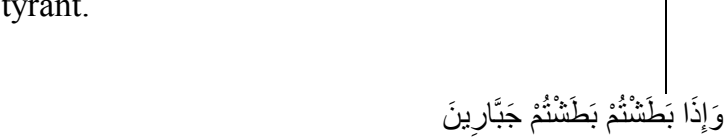

These were the Ad: they rejected their Lord's signs, disobeyed His messengers, and followed the command of every obstinate tyrant.

Sah

And when you strike, you strike as tyrants.

\section{$\mathrm{Ah}$}

Why do you act like tyrants whenever you attack someone?

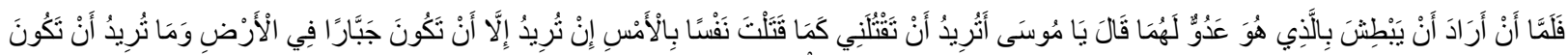
مِنَ الْمُصْنِ كِينَ
}

\section{Sah}

And when he wanted to strike the one who was an enemy to both of them, he said, "O Moses, do you intend to kill me as you killed someone yesterday? You only want to be a tyrant in the land and do not want to be of the amenders."
Ah

As he was about to attack the man who was an enemy to both of them, the man said, 'Moses, are you going to kill me as you killed that person yesterday? You clearly want to be a tyrant in the land; you do not intend to put things right.' 


\section{Sah}

Those who dispute concerning the signs of Allah without an authority having come to them - great is hatred [of them] in the sight of Allah and in the sight of those who have believed. Thus does Allah seal over every heart [belonging to] an arrogant tyrant.

\section{$\mathrm{Ah}$}

those who dispute God's messages, with no authority given to them, are doing something that is loathed by God and by those who believe. In this way God seals up the heart of every arrogant tyrant.

Although the choice of 'tyrant' is somewhat acceptable, it still misses out the repetition implied by Arabic hyperboles. As the Random House Webster's Unabridged Dictionary states, '-ant' denotes 'characterized by or serving in the capacity of', which makes 'tyrant' only like any other adjective. The Arabic hyperbolic form, being used to describe human, indicates 'dislike or abhorrence. This shade of meaning should have been highlighted. A better solution would thus have been 'an abhorred tyrant'.

Hammalah حمالة :

This hyperbolic form occurs in verse 4 of Surah Al-Masad as follows:

$$
\text { وَامْرَأَنَهُهُ حَمَّالَةَ الْحَطَبِ }
$$

The two translations are

\section{Sah}

And his wife [as well] - the carrier of
$\mathrm{Ah}$

and so will his wife, the firewood-carrier

The same problem of repetition recurs. The two translators opt for the morphological strategy. A better translation would have been 'repetitive carrier of firewood'.

Khawwan خوان:

This hyperbolic form occurs in verse 38 of Surah Al- $\underline{H}$ ajj as follows:

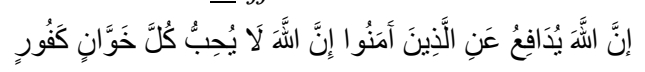

The two translations are:

\section{Sah}

Indeed, Allah defends those who have believed. Indeed, Allah does not like everyone treacherous and ungrateful.
Ah

God will defend the believers; God does not love the unfaithful or the ungrateful.

The meaning of 'khawwan' in Arabic is 'someone who is obstinately treacherous' or 'repetitively betraying' (see Saleh, 2005). The two translators differ in their approach. While the Saheeh translator opts for the morphological solution of the suffix '-ous', which means 'full of', Abdel-Haleem applied litotes by using the prefix 'un-' combined by the suffix '-ful'. Thus, he opts for a semantico-morphological solution. Yet he fails to capture the meaning of obstinacy and repetition. Moreover, the use of litotes invests the context of the translation product with a euphemistic attitude, which harms the meaning. A better solution would have been ' obstinately (repetitively) treacherous'.

Khattar ختار:

This hyperbolic form occurs in verse 32 of Surah Luqman as follows:

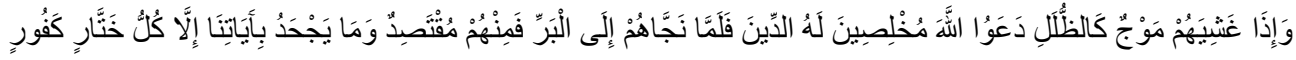




\section{Sah}

And when waves come over them like canopies, they supplicate Allah, sincere to $\mathrm{Him}$ in religion [i.e., faith]. But when $\mathrm{He}$ delivers them to the land, there are [some] of them who are moderate [in faith]. And none rejects Our signs except everyone treacherous and ungrateful.
Ah

When the waves loom over those on board like giant shadows they call out to God, devoting their religion entirely to Him. But, when $\mathrm{He}$ has delivered them safely to land, some of them waver- only a treacherous, thankless person refuses to acknowledge Our signs.

Here the two translators stop short of noticing the hyperbolized form 'khattar': they translate it as if it is 'khatir', i.e. treacherous. A better translation would have been 'habitually treacherous'.

\section{خلاق Khallaq:}

This hyperbolic form occurs in verse 86 of Surah Al- $\underline{H} i j r$ as follows:

$$
\text { إنََّ رَبَّكَ هُوَ الْخَلَّاقُ الْعَلِيُ }
$$

The two translations are:

\begin{tabular}{c|c} 
Sah & Ah \\
Indeed, your Lord $-\mathrm{He}$ is the Knowing Creator. & Your Lord is the All Knowing Creator.
\end{tabular}

The same problem of translating divine attributes recurs. The suffix '-or' only denotes agency, while super-ability, repetition and abundance are lost. A better solution would have been 'All Creating'.

Sabbar صبار:

This hyperbolic form occurs in verse 19 of Surah $\mathrm{Saba}^{\prime}$ as follows:

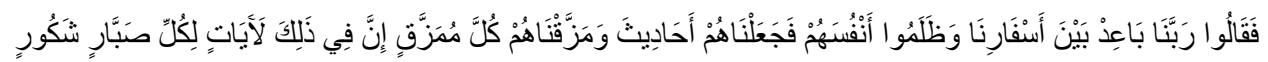

The two translations are as follows:

\section{Sah}

But [insolently] they said, "Our Lord, lengthen the distance between our journeys," and wronged themselves, so We made them narrations and dispersed them in total dispersion. Indeed in that are signs for everyone patient and grateful.

\section{$\mathrm{Ah}$}

but [still] they complained, 'Our Lord has made the distance between our staging posts so long!' They wronged themselves and, in the end, We made their fate a byword, and scattered them in countless fragments. There truly are signs in this for every patient, thankful person.

The two translators flattened the hyperbolic form 'sabbar', i.e. given to patience or extraordinarily patient. This may be due to the etymological account under the entry of 'patient' in the Random House Webster's Unabridged Dictionary: 
Combined with the meaning of 'characterized by or serving in the capacity of included under '-ent', the two translators may have thought that it is enough as an adequate translation. However, an important question is: what about the translation of 'saber', i.e. the non-hyperbolized form of 'sabbar'? A better translation would have been, as stated above, ' given to patience' or 'extraordinarily patient'. The same problem is detected in the following example of verse 33 in Surah Al-Shura:

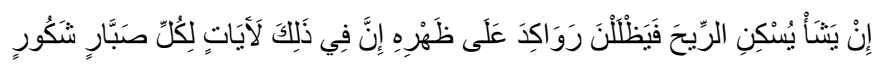

\section{Sah}

If He willed, He could still the wind, and they would remain motionless on its surface. Indeed in that are signs for everyone patient and grateful.

\section{$\mathrm{Ah}$}

if $\mathrm{He}$ willed, $\mathrm{He}$ could bring the wind to a standstill and they would lie motionless on the surface of the sea- there truly are signs in this for anyone who is steadfast and thankful-

The two translators commit the same error.

Kadhab كذاب:

This hyperbolic form occurs in the following verses 24, and 25 and 26 of Surahs Ghafir and Al-Qamar, respectively as follows. The translations are provided after each verse:

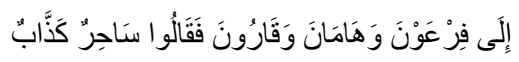

Sah

To Pharaoh, Hamanand Qarun, but they said, "[He is] a magician and a liar."

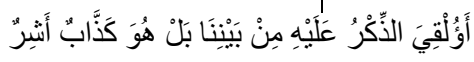

Sah

Has the message been sent down upon him from among us? Rather, he is an insolent liar."

$$
\text { سَبَعْلَمُونَ غَذَا هَنِ الْكَذَّابُ الْالَشِرُ }
$$

Sah

They will know tomorrow who is the insolent
$\mathrm{Ah}$

to Pharaoh, Haman, and Korah and they said, 'Sorcerer! Liar!'

Would a message be given to him alone out of all of us? No, he is an insolent liar!'

liar.

$\mathrm{Ah}$

'Tomorrow they will know who is the insolent

liar

The two translators preserve 'liar' as an adequate translation for 'kazzab'. They disregard the semantic dimension of repetition and habit. A better translation would have been 'mendacious', since the Random House Webster's Unabridged Dictionary includes under it, the following entry:

telling lies, esp. habitually; dishonest; lying; untruthful: a mendacious person.

Manna? مناع:

This hyperbolic form occurs in the following verse 25 of Surah Qaf:

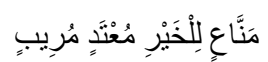


The translations are as follows:

Sah

Preventer of good, aggressor, and doubter,
$\mathrm{Ah}$

everyone who hindered good, was aggressive, caused others to doubt

The two renditions merit some discussion. The Saheeh translator resorts to the morpheme of agency, namely '-er', while Abdel-Haleem utilizes the syntactic property of tense. Abdel-Haleem's translation does more harm to the overall meaning than does the Saheeh one. He uses the simple past, which indicates the termination of the action, and hence the loss of the core meaning of the hyperbolic form. He would have used the present perfect, which would have indicated some continuity of action. A better translation can be 'habitually banning good'.

Hammazii هماز:

The hyperbolic form occurs in the following verse 11 of Surah Al-Qalam:

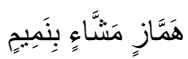

The translations are as follows:

\section{Sah}

[And] scorner, going about with malicious gossip - [And] scorner, going about with malicious gossip -
Ah

to any backbiter, slander-monger

The Saheen translator mistranslates 'hammaz' into 'scorner': 'to scorn' is to ridicule', while 'hammaz' means 'spreading false news about someone'. Abdel-Haleem, on the other hand, fuses the meaning of 'hammaz' into the following adjective, namely 'mashaa'. This is clear if the entry under 'backbiter' is taken into consideration:

1. to attack the character or reputation of (a person who is not present).

v.i.

2. to speak unfavorably or slanderously of a person who is not present.

In the second sense, 'slanderously' is taken to be part of the definition for 'backbiter': Abdel-Haleem includes 'slander' in the translation of 'mashaa' later, coming up with 'slander-monger'. This confusion is unjustified for the morph '-er' of 'backbiter' misses out the implied repetition and habituality of the hyperbolized form 'hammaz'. A better translation can be 'habitual defamator'.

\section{2 Flat (Sah), Comp (Ah)}

Awwab أواب :

The hyperbolic form occurs in the following verse 23 of Surah Qaf:

$$
\text { هَذَا مَا تُو عَدُونَ لِكُلِّ أَوَّابِ حَفِيظٍ }
$$

The translations are as follows:

Sah

[It will be said], "This is what you were promised - for every returner [to Allah] and keeper [of His covenant]

\section{$\mathrm{Ah}$}

'This is what you were promised - this is for everyone who turned often to God and kept Him in mind,

This form occurs in 5.4 above. Here, the Saheeh translator resorts as usual to morphology, using the suffix of agency '-er'. Yet Abdel-Haleem managed to provide an acceptable translation by inserting the adverb 'often' and using the verb form. However, he misses some part of the meaning by using the simple past form. 
The hyperbolic form occurs in the following verse 14 of Surah $\mathrm{Al}-\mathrm{Naba}$ :

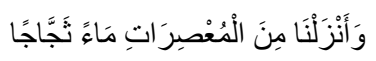

The translations are as follows:

Sah

And sent down, from the rain clouds, pouring water And sent down, from the rain clouds, pouring water
$\mathrm{Ah}$

Did We not send water pouring down

from the clouds

The Saheen translator seems to be content with 'pouring' as sufficient for 'thajjaj', while Abdel-Haleem adds the preposition 'down'. In fact, the Saheeh translator fails to capture the quantity and quality implied in 'thajjaj', which means 'copious'. The morph '-ing' is just a marker of the adjective, and does not imply even continuity. This is why Abdel-Haleem opts for adding the preposition and transforms the Arabic adjective into a reduced English clause. His solution is better and conveys the full sense of 'thajjaj' only syntactically. Another successful rendition would have been a combination of adjective and a reduced clause, namely 'water copiously pouring down'.

Zلام Zallam:

The hyperbolic form occurs in the following verse 29 of Surah Fussilat:

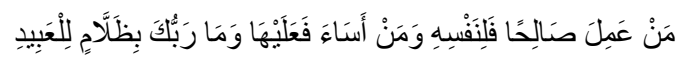

The translations are as follows:

\section{Sah}

The word [i.e., decree] will not be changed with $\mathrm{Me}$, and never will I be unjust to the servants."

\section{$\mathrm{Ah}$}

and My word cannot be changed: I am not unjust to any creature.'

The Saheeh translator applies the syntactic solution of ' never will I be unjust', which is not accurate. The use of the future tense with the particle 'never' confines the quality of justness to the time ahead, not the continuity and quantity implied by the hyperbolized form. Moreover, the use of the interrogative mood renders the entire context questionable, which significantly detracts from the overall meaning. What Abdel-Haleem does is clearly more acceptable. He uses the double negative construction, coupled with the use of 'any' later in the same context, to emphasize the quality of justness. This clearly compensate for the loss of the hyperbolic form 'zallam'.

?لام allam:

The hyperbolic form occurs in the following verse 109 of Surah Al-Ma'idah:

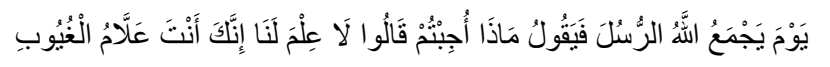

The translations are as follows:

Sah

[Be warned of] the Day when Allah will assemble the messengers and say, "What was the response you received?" They will say, "We have no knowledge. Indeed, it is You who is Knower of the unseen" -
$\mathrm{Ah}$

On the Day when God assembles all the messengers and asks, 'What response did you receive?' they will say, 'We do not have that knowledge: You alone know things that cannot be seen.'

The Saheeh translator insists on resorting to morphology by just adding the agency morph '-er'. Abdel-Haleem, as usual, attempts to compensate for loss by means of syntactic shifts. He turns the Arabic adjective into a simple 
present tense verb, namely 'know', and adds the clarifying string 'things that cannot be seen'. This may compensate for the mandatory loss of the hyperbolic form. Another adequate rendition would have been 'the All-Knowing of the unseen matters'. Abdel-Haleem applies the same strategy of syntactic shifting and addition in all the other occurrences of the same hyperbolic form in the other verses and Surahs as follows:

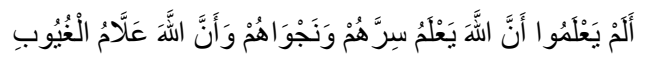

\section{Sah}

Did they not know that Allah knows their secrets and their private conversations and that Allah is the Knower of the unseen?
$\mathrm{Ah}$

Do they not realize that God knows their secrets and their private discussions? That God knows all that is hidden?

$$
\text { قُلْ إِنَّ رَبِّي يَقْذِفُْ بِالْحَقِّ عَلَّمُ الْغُيُوبِ }
$$

\section{Sah}

Say, "Indeed, my Lord projects the truth, Knower of the unseen."

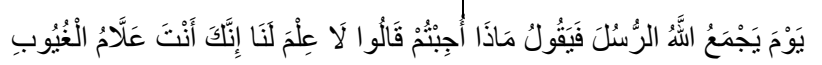

Ah

Say, 'My Lord hurls the Truth down [before you]. He has full knowledge of all that is unseen.
Sah

[Be warned of] the Day when Allah will assemble the messengers and say, "What was the response you received?" They will say, "We have no knowledge. Indeed, it is You who is Knower of the unseen" -
$\mathrm{Ah}$

On the Day when God assembles all the messengers and asks, "What response did you receive?' they will say, 'We do not have that knowledge: You alone know things that cannot be seen.'

It is clear that Abdel-Haleem further adds the adjectives 'full' and 'all', respectively, which well convey the intended meaning.

Fa??al فعال:

The hyperbolic form occurs in the following verse 16 of Surah Al-Burooj:

$$
\text { فَعَّالْ لِمَّا يُرِيدُ }
$$

The translations are as follows:

Sah

Effecter of what He intends.
Ah

He does whatever He will.

The Saheeh translator flattens the hyperbolic form by means of semantics and morphology. She selects the morphological form 'effecter' to imply the ability of transforming something. Abdel-Haleem, however, opts for the simple present verb form 'does' followed by 'whatever', unlike the Saheeh translator who uses 'what' after 'effecter'. What Abdel-Haleem does is slightly more accurate, since he implies habit by means of the simple aspect of the verb, and adds 'whatever' to complement the loss of meaning.

Fattah فتاح:

The hyperbolic form occurs in the following verse 26 of Surah $S a b a^{\prime}$ :

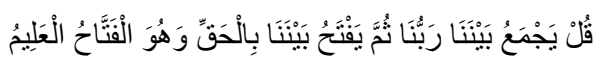

The translations are as follows: 
Sah

Say, "Our Lord will bring us together; then $\mathrm{He}$ will judge between us in truth. And $\mathrm{He}$ is the Knowing Judge."
$\mathrm{Ah}$

Say, 'Our Lord will gather us together, then $\mathrm{He}$ will judge justly between us; He alone is the All Knowing Judge.'

The Saheeh translator again forms the adjective using the suffix '-ing', while Abdel-Haleem relies on syntactic shifts or transposition coupled with clarification. This difference between the two translators may be attributed to the laziness of the Saheeh translator, who does not see the difference between the Arabic hyperbolic form 'fattah' and the active participle 'fateh'.

\section{Sahhar سحار :}

The hyperbolic form occurs in the following verse 37 of Surah $A l-S h u ? \mathrm{ra}^{\prime}$ :

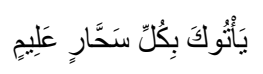

The translations are as follows:

Sah
$\begin{aligned} & \text { Who will bring you every learned, skilled } \\ & \text { magician." }\end{aligned}$

Abdel-Haleem aptly selects 'sorcerer' rather than 'magician', which refers to someone who takes magic for entertainment. His choice depends on the meaning of 'sorcery' as a profession.

Qahhar قهار:

The hyperbolic form occurs in the following verse 39 of Surah Yusuf:

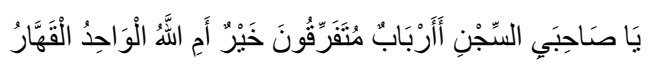

The translations are as follows:

\section{Sah}

O [my] two companions of prison, are separate lords better or Allah, the One, the Prevailing?
Fellow prisoners,

would many diverse gods be better than God the One, the All Powerful? [No indeed!]

The Saheeh translator flattens the hyperbolic form by using the adjective-cum-noun 'prevailing', while Abdel-Haleem resorts to the more English-sounding 'All-Powerful'. His rendition is more accurate, since the use of the prefix 'all-' implies omnipotence and unlimited power. Abdel-Haleem also uses the prefix 'over-' for the same purpose in the following verse 48 in Surah Ibrahim:

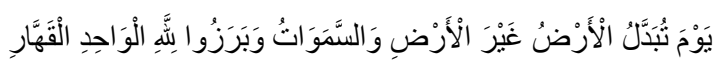

Sah

[It will be] on the Day the earth will be replaced by another earth, and the heavens [as well], and they [i.e., all creatures] will come out before Allah, the One, the Prevailing,

Wahhab وهاب:
$\mathrm{Ah}$

One Day- when the earth is turned into another earth, the heavens into another heaven, and people all appear before God, the One, the Overpowering-

The hyperbolic form occurs in the following verse 8 of Surah $A l$-?Imran : 
The translations are as follows:

\section{Sah}

[Who say], "Our Lord, let not our hearts deviate after You have guided us and grant us from Yourself mercy. Indeed, You are the Bestower.
Ah

'Our Lord, do not let our hearts deviate after You have guided us. Grant us Your mercy: You are the Ever Giving.

The Saheeh translator, as is the case in the present instance and the ones to follow, sticks to the morphological solution. However, Abdel-Haleem is better equipped for the nuances of the hyperbolic forms. He adds the suffix 'all-' and the superlative 'most', coupled with the morph '-ous' to denote fullness. The following examples well illustrate this strategy.

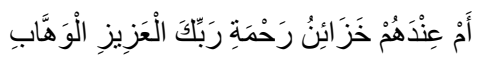

Sah

Or do they have the depositories of the mercy of your Lord, the Exalted in Might, the Bestower?
Ah

Do they possess the treasures of your Lord's bounty, the Mighty, the All Giving?

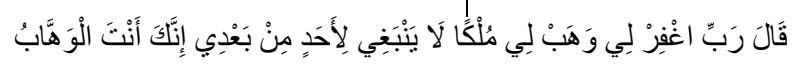

\section{Sah}

He said, "My Lord, forgive me and grant me a kingdom such as will not belong to anyone after me. Indeed, You are the

Bestower."
$\mathrm{Ah}$

He turned to Us and prayed: 'Lord forgive me! Grant me such power as no one after me will have- You are the Most Generous Provider.'

Wahhaj وهاج:

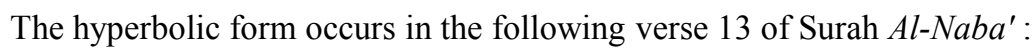

$$
\text { وَجَعَلْنَا سِرِاجَا وَهَّاجًا }
$$

The translations are as follows:

Sah

And made [therein] a burning lamp and make a blazing lamp?

The hyperbolic form here indicates intensity and brightness or resplendence (cf. Saleh, 2005). This is fully encoded in 'blazing', which the Random House Webster's Unabridged Dictionary defines as:

1. burning brightly and with great heat, force, etc.

2. of tremendous intensity or fervor.

Thus, Abdel-Haleem succeeds in conveying the meaning in one word, while the Saheeh translator opts for the deverbal 'burning', a hypernym lacking any specificity.

\subsection{Flat (Sah), Partial (Ah)}

Affak أفاك::

The hyperbolic form occurs in the following verse 7 of Surah Al-Jathiyah as follows:

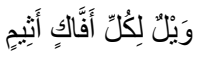

The translations are as follows: 
The same hyperbolic form also occurs in verse 222 of Surah $A l-S h u ? r a^{\prime}$ :

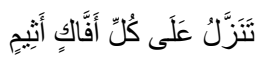

The two translations are:

Sah

They descend upon every sinful liar.
$\mathrm{Ah}$

They come down to every lying sinner

As is the case with translating 'al-sayyarah' below, the two translators opt for the morphological strategy. The Saheeh translator just attaches the morph '-ar', while Abdel-Haleem uses the deverbal adjective 'lying' to imply continuity. However, he fails to convey the meaning of the hyperbolic form. A better translation would have been 'maliciously habitual liar'.

Al-Sayyarah السيارة :

The hyperbolic form occurs in the following verse 10 of Surah Yusuf:

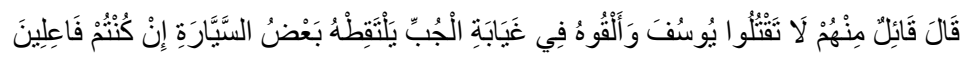

The translations are as follows:

\section{Sah}

Said a speaker among them, "Do not kill Joseph but throw him into the bottom of the well; some travelers will pick him up - if you would do [something]."
Ah

[Another of them] said, 'Do not kill Joseph, but, if you must, throw him into the hidden depths of a well where some caravan may pick him up.'

The Saheeh translator opts for the easy solution: morphological shift. Abdel-Haleem, on the other hand, selects the semantic equivalent, namely 'caravan', to imply that traveling is a habit. Yet he misses the repetitive meaning of the hyperbolic form. A better solution would have been 'habitual caravan'.

\section{خلاق Khallaq :}

The hyperbolic form occurs in the following verse 81 of Surah Ya-Seen:

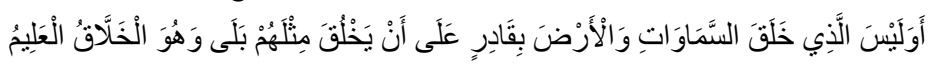

The translations are as follows:

\section{Sah}

Is not He who created the heavens and the earth Able to create the likes of them? Yes, [it is so]; and He is the Knowing Creator.
Ah

Is He who created the heavens and earth not able to create the likes of these people? Of course He is! He is the All Knowing Creator:

Although the two translators concur that 'creator' is the best translation for 'khallaq', Abdel-Haleem adds the prefix 'all-' to capture the omnipotence aspect of the divine name. Yet he loses the repetitive aspect. A better translation would have been the 'All Creating'.

Jabbar جبار:

The hyperbolic form occurs in the following verses 14, 32, and 45 of Surahs Mariam and Qaf, respectively: 


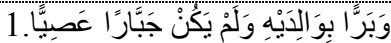

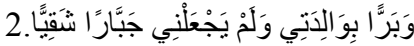

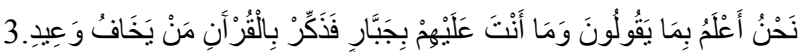

The translations are, respectively, as follows:

1.

Sah

And dutiful to his parents, and he was not a disobedient tyrant.
$\mathrm{Ah}$

kind to his parents, not domineering or rebellious.

2.

Sah

And [made me] dutiful to my mother, and $\mathrm{He}$ has not made me a wretched tyrant.
$\mathrm{Ah}$

to cherish my mother. He did not make me domineering or graceless.

3.

\section{Sah}

We are most knowing of what they say, and you are not over them a tyrant. But remind by the Qur'an whoever fears My threat.
$\mathrm{Ah}$

We know best what the disbelievers say. You [Prophet] are not there to force them, so remind, with this Qur'an, those who fear My warning.

The hyperbolic form 'jabbar' in these instances is not a divine attribute: it lacks the limitless power and ubiquity implied by the divine name. This is why the two translators prefer to confine their choices to less evocative words. However, Abdel-Haleem tries to utilize syntax and semantics to serve the purposes of implying some continuity. Thus he translates it as 'domineering' and 'to force', respectively. The two choices are informed by his wish to use the adjective 'domineering', which is semantically related to kinship relationships according to the Random House Webster's Unabridged Dictionary. He also uses the verb 'to force' when the context refers to the Prophet Muhammad, so that the kinship connotations are ruled out. Moreover, the use of the simple present retains some of the meaning of the hyperbolic forms. A better solution would have been the addition of the adverb 'habitually' or 'repetitively' before 'domineering' and before 'force'.

Kadhab كذاب:

The hyperbolic form occurs in the following verse 4 of Surah Sad:

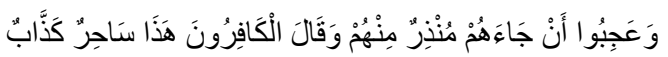

The translations are as follows:

\section{Sah}

And they wonder that there has come to them a warner [i.e., Prophet Muhammad ( صلى اله [(عليه وسلم from among themselves. And the disbelievers say, "This is a magician and a liar.

\section{$\mathrm{Ah}$}

The disbelievers think it strange that a prophet of their own people has come to warn them: they say, 'He is just a lying sorcerer. 
The Saheeh translator sticks to the morphological equivalent, while Abdel-Haleem again resorts to the syntactic shift of the deverbal. However, in another instance, he opts for topographical and pragmatic solutions as follows:

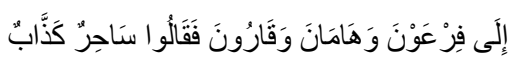

\section{Sah}

To Pharaoh, Haman and Qarunn, but they said, "[He is] a magician and a liar."
Ah

to Pharaoh, Haman, and Korah and they said, 'Sorcerer! Liar!'

It is clear that Abdel-Haleem uses the exclamation mark for pragmatic purposes. He attempts to compensate for the loss of meaning on the pragmatic level of invectives.

Kaffar كفار:

The hyperbolic form occurs in the following verse 276 of Surah Al-Baqarah:

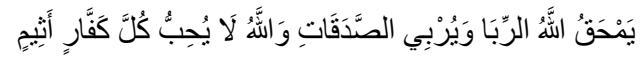

The translations are as follows:

\section{Sah}

Allah destroys interest and gives increase for charities. And Allah does not like every sinning disbeliever.
Ah

God blights usury, but blesses charitable deeds with multiple increase: He does not love the ungrateful sinner.

Abdel-Haleem, unlike the Saheeh translator, preserves the order of the two hyperbolized forms 'kaffar' and 'atheem ${ }^{\text {iii }}$ to allow for the use of the adjective 'ungrateful'. Yet he misses on the repetitive aspect of 'kaffar'. A better solution would have been 'the repetitively unappreciative sinner'.

\section{Nazza? نز اع:}

The hyperbolic form occurs in the following verse 16 of Surah Al-Ma?arij :

$$
\text { نَزَّاعَةً للِشَّوَى }
$$

The translations are as follows:

$\mathrm{Sah}$

A remover of exteriors.
Ah that strips away the skin

As usual, the Saheeh translator applies morphological shifting, while Abdel-Haleem opts for syntactic transposition. He compensates for the loss of meaning by means of adding the preposition 'away'. A better solution can be 'that will be stripping away the skin'.

\subsection{Comp (Sah), Comp (Ah)}

Ammarah أمارة:

The hyperbolic form occurs in the following verse 53 of Surah Yusuf:

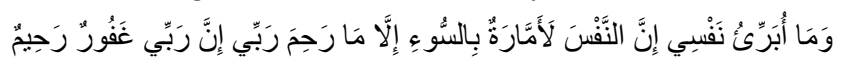

The translations are as follows: 
And I do not acquit myself. Indeed, the soul is a persistent enjoiner of evil, except those upon which my Lord has mercy.

Indeed, my Lord is Forgiving and Merciful."
I do not pretend to be blameless, for man's very soul incites him to evil unless my Lord shows mercy: He is most forgiving, most merciful.'

Both translators succeed in conveying the meaning intended. The Saheeh translator prefers to render the hyperbolic form in question into an adjective + noun, i.e. 'persistent enjoiner'. The choice of 'persistent' is well grounded, since it entails repetition and habit. Abdel-Haleem also applies syntactic transposition to capture the meaning of continuity by means of the simple present form of the verb 'incite'. He, moreover, applies explicitation by adding 'man's very'.

\section{Khawwan خوان:}

The hyperbolic form occurs in the following verse 107 of Surah Al-Nisa':

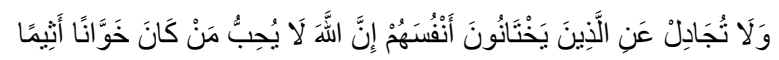

The translations are as follows:

Sah

And do not argue on behalf of those who deceive themselves. Indeed, Allah loves not one who is a habitually sinful deceiver.
$\mathrm{Ah}$

Do not argue for those who betray their own souls: God does not love anyone given to treachery and $\sin$.

Both translators succeed in conveying the meaning of the hyperbolic form despite the fact that the Saheeh translator intricately does so. She inserts the adverb 'habitually', which in turn qualifies 'sinful', which typically qualifies 'deceiver'. The problem is that of proximity, yet the context clarifies it. On the other hand, Abdel-Haleem selects the transparent idiom 'given to' to imply repetition and persistence, followed by the noun 'treachery'.

\section{Tawwab تواب:}

The hyperbolic form occurs in the following verse 16 of Surah Al-Nisa':

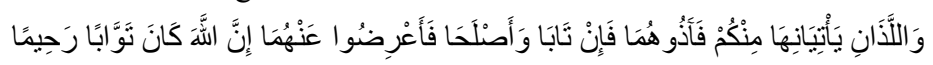

The translations are as follows:

\section{Sah}

And the two who commit it [i.e., unlawful sexual intercourse] among you - punish [i.e., dishonor] them both. But if they repent and correct themselves, leave them alone. Indeed, Allah is ever Accepting of repentance and Merciful.
$\mathrm{Ah}$

If two men commit a lewd act, punish them both; if they repent and mend their ways, leave them aloneGod is always ready to accept repentance, He is full of mercy.

The two translators fully utilize syntactic transposition. The Saheeh translator adds the prefix 'ever' and uses the present participle form of 'accept. Thus, she manages to convey the meaning of omnipotence as implied by the divine name. Abdel-Haleem in turn syntactically applies explicitation through the lengthy string 'always ready to accept', which entails continuity and limitless power. The same strategies are observed in the following verse of Surah Al-Nas $r$ :

$$
\text { فَسَبِّحْ بِحَمْدِ رَبِّكَ وَاسْتَغْفْرْهُ إِنَّهُ كَانَ تَوَّابًَا }
$$

The translations are as follows:

Sah

Then exalt [Him] with praise of your Lord and ask forgiveness of Him. Indeed, $\mathrm{He}$ is ever Accepting of repentance.
Ah

celebrate the praise of your Lord and ask His forgiveness: $\mathrm{He}$ is always ready to accept repentance. 


\section{Samma? سماع:}

The hyperbolic form occurs in the following verse 41of Surah Al-Ma'idah:

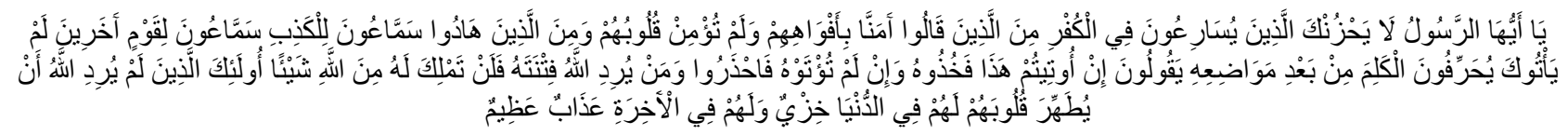

The translations are as follows:

Sah

O Messenger, let them not grieve you who hasten into disbelief of those who say, "We believe" with their mouths, but their hearts believe not, and from among the Jews. [They are] avid listeners to falsehood, listening to another people who have not come to you. They distort words beyond their [proper] places [i.e., usages], saying, "If you are given this, take it; but if you are not given it, then beware." But he for whom Allah intends fitnah - never will you possess [power to do] for him a thing against Allah. Those are the ones for whom Allah does not intend to purify their hearts. For them in this world is disgrace, and for them in the Hereafter is a great punishment.
$\mathrm{Ah}$

Messenger, do not be grieved by those who race to surpass one another in disbelief- those who say with their mouths, 'We believe,' but have no faith in their hearts, and the Jews who listen eagerly to lies and to those who have not even met you, who distort the meanings

of [revealed] words and say [to each other], 'If you are given this ruling, accept it, but if you are not, then beware!' - if God intends some people to be so misguided, you will be powerless against God

on their behalf. These are the ones whose hearts God does not intend to cleanse- a disgrace for them in this world, and then a heavy punishment in the Hereafter-

As is the case in 5.5, the Saheeh translator rightly renders the first hyperbolic form into 'avid listeners', while the second one is flattened. Abdel-Haleem uses the adverb 'eagerly', but also deletes the second hyperbole by dint of ellipsis. The same is true for the following verse in Surah Al-Ma'idah:

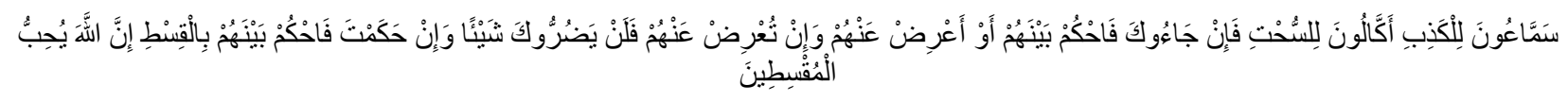

Sah

[They are] avid listeners to falsehood, devourers of [what is] unlawful. So if they come to you, [O Muhammad], judge between them or turn away from them. And if you turn away from them - never will they harm you at all. And if you judge, judge between them with justice. Indeed, Allah loves those who act justly.
$\mathrm{Ah}$

they listen eagerly to lies and consume what is unlawful. If they come to you [Prophet] for judgement, you can either judge between them, or decline- if you decline, they will not harm you in any way, but if you do judge between them, judge justly: God loves the just-

Naddakhah نضاخة:

The hyperbolic form occurs in the following verse 66 of Surah Al-Rahman:

$$
\text { فِيرهَِا عَبْنَانِ نَضَّاخَتَانِ }
$$

The translations are as follows:

\section{Sah}

In both of them are two springs, spouting.
$\mathrm{Ah}$

With a pair of gushing springs.

According to standard Arabic dictionaries, 'nadakhah' means the sprinkling of water in certain quantities. The hyperbolic form thus adds the aspect of profuseness or repetition. The Saheeh translator uses the adverbial phrase 'spouting', which only qualifies the noun? Abdel-Haleem, on the other hand, uses the adjective form to produce a wellformed sentence. The two translators thus select the adequate word, but the Saheeh translator errs on the side of caution. 


\section{Zallam ظلام:}

The hyperbolic form occurs in the following verse 182 of Surah Al-?Imran:

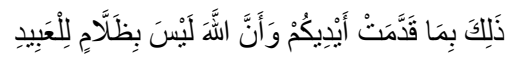

The translations are as follows:

\section{Sah}

That is for what your hands have put forth and because Allah is not ever unjust to [His] servants.

\section{$\mathrm{Ah}$}

That is on account of what you stored up for yourselves with your own hands: God is never unjust to His servants.'

The two translators typically add 'ever' and 'never' to the qualifying adjective 'unjust'. They thus capture the meaning of time as implied by the hyperbolic form. The same practice is observed in the translation of the following verses:

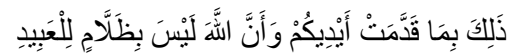

\section{Sah}

That is for what your hands have put forth [of evil] and because Allah is not ever unjust to His servants."

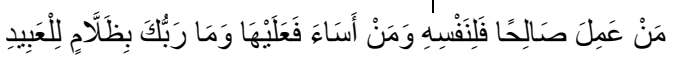

Sah

Whoever does righteousness - it is for his [own] soul; and whoever does evil [does so] against it. And your Lord is not ever unjust to [His] servants.
$\mathrm{Ah}$

This is caused by what your own hands have stored up for you: God is never unjust to His creatures.'
$\mathrm{Ah}$

Whoever does good does it for his own soul and whoever does evil does it against his own soul: your Lord is never unjust to His creatures.

Ghaffar غفار:

The hyperbolic form occurs in the following verse 82 of Surah Ta-ha:

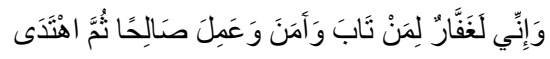

The translations are as follows:

\section{Sah}

But indeed, I am the Perpetual Forgiver of whoever repents and believes and does righteousness and then continues in guidance.
$\mathrm{Ah}$

Yet I am most forgiving towards those who repent, believe, do righteous deeds, and stay on the right path.'

The two translators apply syntactic transposition. The Saheeh translator rightly selects the adjective 'perpetual' to qualify 'forgiver', capitalizing the initial to introduce a neologism. One reason for the accurate rendition here may be the laam of emphasis in ghaffar? Abdel-Haleem, for his part, chooses 'most' to cover both time and quantity. The same practice is observed in the translation of the following verse 66 in Surah $\underline{\mathrm{Sad}}$ :

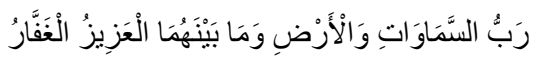

\section{Sah}

Lord of the heavens and the earth and whatever is between them, the Exalted in Might, the Perpetual Forgiver."
$\mathrm{Ah}$

Lord of the heavens and earth and everything between, the Almighty, the Most Forgiving.' 
Awwah أو اه :

The hyperbolic form occurs in the following verse 75 of Surah Hud:

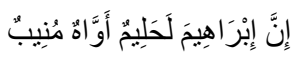

The translations are as follows:

Sah

Indeed, Abraham was forbearing, grieving and [frequently] returning [to Allah].
$\mathrm{Ah}$

for Abraham was forbearing, tender-hearted, and devout.

The same hyperbolic form has been discussed above in section 5.1. Although the Saheeh translator flattens it above, she manages to convey the meaning this time by adding the intratextual gloss 'frequently'. However, Abdel-Haleem flattens it for the second time, using the epithet 'tender-hearted'.

Samma? سماع:

The hyperbolic form occurs in the following verse 47 of Surah Al-Tawbah:

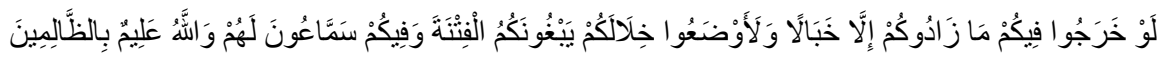

The translations are as follows:

\section{Sah}

Had they gone forth with you, they would not have increased you except in confusion, and they would have been active among you, seeking [to cause] you fitnah [i.e., chaos and dissension]. And among you are avid listeners to them. And Allah is Knowing of the wrongdoers.

\section{$\mathrm{Ah}$}

They would only have given you trouble if they had gone out [to battle] with you: they would have scurried around, trying to sow discord among you, and some of you would willingly have listened to them- God knows exactly who does evil.

The Saheeh translator rightly renders the hyperbolic form into 'avid listeners', while Abdel-Haleem uses the counterfactual 'would willingly have listened'. He thus obliterates the meaning of the hyperbolic form.

غساق Ghassaq:

The hyperbolic form occurs in the following verse 25 of Surah $\mathrm{Al-Naba'}$ :

$$
\text { إلآلَّ حَمِيمًا وَغَسَّاقًا }
$$

The translations are as follows:

\section{Sah}

Except scalding water and [foul] purulence

\section{$\mathrm{Ah}$} except one that is scalding and dark -

The Saheeh translator succeeds in conveying the full meaning of the hyperbolic form. According to Almo'jam alWaseet Dictionary, 'ghassaq' refers to the excess of wrongdoer's burning skin and purulence'. Al-Sihah dictionary adds the meaning of 'foul'. Thus the Saheeh translation succeeds in conveying the meaning, though 'foul' is glossed intratextually. Abdel-Haleem, in contrast, fails to capture the meaning. He resorts to the surface sense of 'ghassaqa', i.e. 'to darken'. Yet he refers the reader to a previous verse in Surah Sad, where the same hyperbolic form occurs and is translated differently: 
Sah

This - so let them taste it - is scalding water and [foul] purulence
$\mathrm{Ah}$

all this will be theirs: let them taste it- a scalding, dark, foul fluid.

Here Abdel-Haleem adds 'foul', but he still omits to insert 'purulent'.

\section{Qawwam قوام:}

The hyperbolic form occurs in the following verse 135 of Surah Al-Nisa':

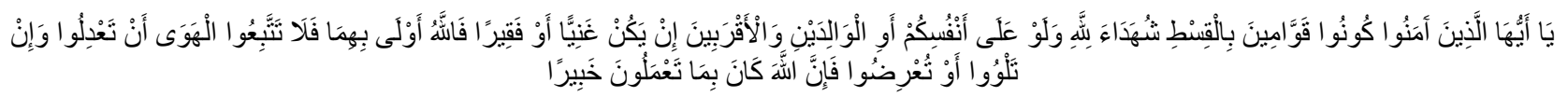

The translations are as follows:

Sah

O you who have believed, be persistently standing firm in justice, witnesses for Allah, even if it be against yourselves or parents and relatives. Whether one is rich or poor, Allah is more worthy of both. So follow not [personal] inclination, lest you not be just. And if you distort [your testimony] or refuse [to give it], then indeed Allah is ever, with what you do, Acquainted.
$\mathrm{Ah}$

You who believe, uphold justice and bear witness to God, even if it is against yourselves, your parents, or your close relatives. Whether the person is rich or poor, God can best take care of both. Refrain from following your own desire, so that you can act justlyif you distort or neglect justice, God is fully aware of what you do.

The Saheeh translator uses the imperative mood with 'be' + 'adverb' + 'adjective' + 'adjective, while Abdel-Haleem uses the same mood but with 'verb' + 'noun'. The Saheeh translator's choice seems to be more elaborate and so it is more accurate: the use of 'be' gives the meaning of 'remain' and 'having the basic quality', and the addition of 'persistently' captures the dimension of time. However, Abdel-Haleem's translation flattens the hyperbolic form: it only means 'support justice'.

\subsection{Comp (Sah), Partial (Ah)}

Awwab أواب:

The hyperbolic form occurs in the following verse 25 of Surah Al-Isra':

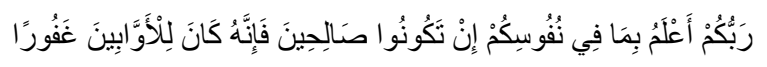

The translations are as follows:

\section{Sah}

Your Lord is most knowing of what is within yourselves. If you should be righteous [in intention] - then indeed $\mathrm{He}$ is ever, to the often returning [to Him], Forgiving.
$\mathrm{Ah}$

Your Lord knows best what is in your heart. If you are good, He is most forgiving to those who return to Him.

The Saheeh translator applies syntactic transposition by means of explicitation. She turns 'awwabeen' (i.e. the plural form of 'awwab') into an adverb + deverbal string, while Abdel-Haleem opts for a simple present verb. Thus AbdelHaleem fails to capture the repetitive aspect of repenting as indicated by the hyperbolic form. 
Tawwaf طواف:

The hyperbolic form occurs in the following verse 58 of Surah Al-Nur:

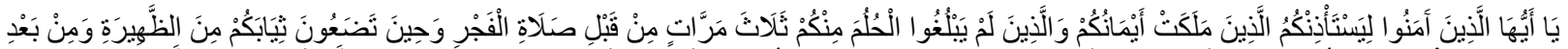

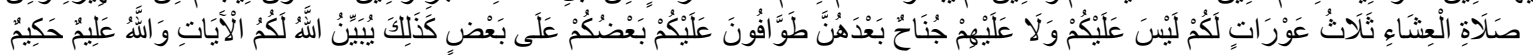

The translations are as follows:

\section{Sah}

O you who have believed, let those whom your right hands possess and those who have not [yet] reached puberty among you ask permission of you [before entering] at three times: before the dawn prayer and when you put aside your clothing [for rest] at noon and after the night prayer. [These are] three times of privacy for you. There is no blame upon you nor upon them beyond these [periods], for they continually circulate among you some of you, among others. Thus does Allah make clear to you the verses [i.e., His ordinances]; and Allah is Knowing and Wise.
$\mathrm{Ah}$

Believers, your slaves and any who have not yet reached puberty should ask your permission to come in at three times of day: before the dawn prayer; when you lay your garments aside in the midday heat; and after the evening prayer. These are your three times for privacy; at other times, there is no blame on you or them if you move around each other freely. In this way God makes messages clear:

God is all knowing, all wise.

The Saheeh translator again resorts to syntactic transposition by means of explicitation. She inserts the adverb 'continually' to capture the basic semantic aspect of exaggeration as denoted by the hyperbole. Abdel-Haleem's translation resorts to the simple present to capture only one part of the meaning.

Ghaffar غفار:

The hyperbolic form occurs in the following verse 5 of Surah Al-Zuammar:

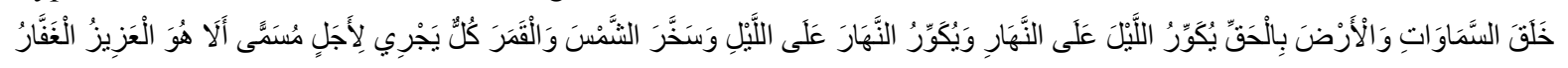

The translations are as follows:

Sah

You invite me to disbelieve in Allah and associate with Him that of which I have no knowledge, and I invite you to the Exalted in Might, the Perpetual Forgiver.
Ah

You call me to disbelieve in God and to associate with Him things of which I have no knowledge; I call you to the Mighty, the Forgiving One.

The Saheeh translator rightly selects the adjective 'perpetual' to qualify 'forgiver', capitalizing the initial to introduce a neologism. Abdel-Haleem, however, partially conveys the meaning intended by opting for the deverbal 'forgiving'. The same difference can be observed in the following verse 42 of Surah Ghafir :

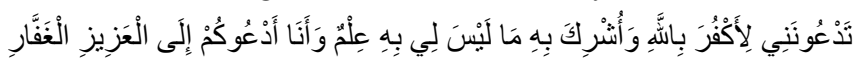

Sah

You invite me to disbelieve in Allah and associate with Him that of which I have no knowledge, and I invite you to the Exalted in Might, the Perpetual Forgiver.
$\mathrm{Ah}$

You call me to disbelieve in God and to associate with Him things of which I have no knowledge; I call you to the Mighty, the Forgiving One.

Kaffar كفار:

The hyperbolic form occurs in the following verse 3 of Surah Al-Zummar:

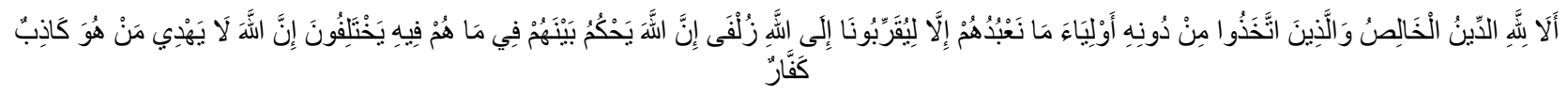


Sah

Unquestionably, for Allah is the pure religion. And those who take protectors besides Him [say], "We only worship them that they may bring us nearer to Allah in position." Indeed, Allah will judge between them concerning that over which they differ. Indeed, Allah does not guide he who is a liar and [confirmed] disbeliever.
Ah

true devotion is due to God alone. [As for] those who choose other protectors beside Him, saying, 'We only worship them because they bring us nearer to God,' God Himself will judge between them regarding their differences. God does not guide any ungrateful liar.

The Saheeh translator adds the explicit adjective 'confirmed' between brackets to elaborate on the meaning of 'kaffar', while Abdel-Haleem chooses the adjective 'ungrateful', thus changing the order of the two epithets 'kaffar' and 'kazzab'. He fails to convey the meaning of 'established disbelief' as denoted by the hyperbole. The same is observed in the following verse in Surah $N u \underline{h}$ :

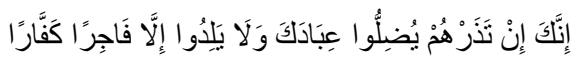

Sah

Indeed, if You leave them, they will mislead Your servants and not beget except [every] wicked one and [confirmed] disbeliever.
Ah

if you leave them they will lead Your servants astray and beget only sinners and disbelievers-

And in the following verse of Surah Qaf:

$$
\text { أَلَفْيَا فِي جَهَنَّمَ كُلَّ كَفَّارٍ عَنيدٍ }
$$

The two translations are

Sah

[Allah will say], "Throw into Hell every obstinate disbeliever,
Ah

'Hurl every obstinate disbeliever into Hell

Tawwab تواب:

The hyperbolic form occurs in the following verse 222 of Surah Al-Baqarah:

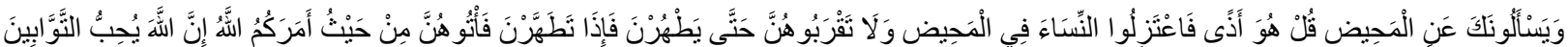

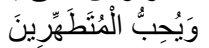

The translations are as follows:

\section{Sah}

And they ask you about menstruation. Say, "It is harm, so keep away from wives during menstruation. And do not approach them until they are pure. And when they have purified themselves, then come to them from where Allah has ordained for you. Indeed, Allah loves those who are constantly repentant and loves those who purify themselves."
$\mathrm{Ah}$

They ask you [Prophet] about menstruation. Say, 'Menstruation is a painful condition, so keep away from women during it. Do not approach them until they are cleansed; when they are cleansed, you may approach them as God has ordained. God loves those who turn to Him, and He loves those who keep themselves clean. 
of or characterized by'). This makes the meaning even clearer. Abdel-Haleem, however, insists on using the simple present form, which misses much of the meaning.

5.7 Partial (Sah), Partial (Ah)

Kaffar كفار:

The hyperbolic form occurs in the following verse 34 of Surah Ibrahim:

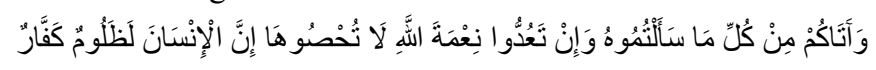

The translations are as follows:

\section{Sah}

And He gave you from all you asked of Him. And if you should count the favor [i.e., blessings] of Allah, you could not enumerate them. Indeed, mankind is [generally] most unjust and ungrateful.

\section{$\mathrm{Ah}$}

and given you some of everything you asked Him for. If you tried to count God's favours you could never calculate them: man is truly unjust and ungrateful.

Although the Saheeh translator has succeeded in accurately rendering this hyperbole before in section 5.6 above, she selects 'ungrateful' in the context at issue. This may reflect inconsistency on her part, or the laziness of the editor(s). Abdel-Haleem, in contrast, remains consistent in partially conveying the meaning of the hyperbole.

Kناس Kناس:

The hyperbolic form occurs in the following verse 4 of Surah Al-Naas:

$$
\text { مِنْ شَرِّ الْوَسْوَسِ الْنَنَّاسِ }
$$

The translations are as follows:

Sah

From the evil of the retreating whisperer -
$\mathrm{Ah}$ against the harm of the slinking whisperer

The problem here is not syntactic but rather semantic, being dependent on word-choice. Both translators err on the side of caution. The Saheeh translator selects 'retreating' while Abdel-Haleem uses 'slinking'. Although both translators do not insert any adverb to denote continuity or repetition, Abdel-Haleem succeeds in selecting 'slink', which, according to the Random House Webster's Unabridged Dictionary, means 'to move or go in a furtive, abject manner, as from fear, cowardice, or shame.'

\section{Qawwam قوام:}

The hyperbolic form occurs in the following verse 34 of Surah Al-Nisa':

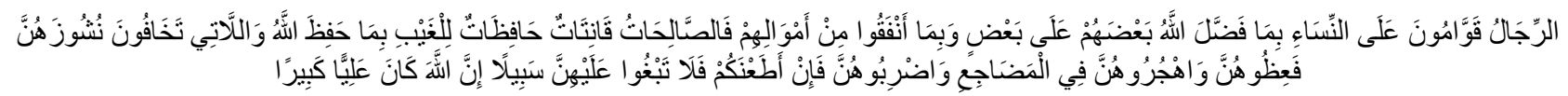

The translations are as follows:

Sah

Men are in charge of women by [right of] what Allah has given one over the other and what they spend [for maintenance] from their wealth. So righteous women are devoutly obedient, guarding in [the husband's] absence what Allah would have them guard. But those [wives] from whom you fear arrogance - [first] advise them; [then if they persist], forsake them in bed; and
$\mathrm{Ah}$

Husbands should take good care of their wives, with [the bounties] God has given to some more than others and with what they spend out of their own money. Righteous wives are devout and guard what God would have them guard in their husbands' absence. If you fear high-handedness from your wives, remind them [of the teachings of God], then ignore them when you go to bed, then 
[finally], strike them. But if they obey you hit them. If they obey you, you have no right to act [once more], seek no means against them. against them: God is most high and great.

Indeed, Allah is ever Exalted and Grand.

Due to the absence of the notion of 'qawamah' in English, which in Arabic means 'take care of and be just to someone', the two translators attempt to paraphrase the hyperbolized form 'qawwam'. Yet the strategy of paraphrase inherently allows the translator to capture the full meaning. The Saheeh translator fails to take advantage of this strategy to the full: the simple present tense used implies habit but not quantity. What Abdel-Haleem does is, using the deontic 'should' and adding 'good' before the 'care'. This partially compensates for the loss of the hyperbolic form, but causes another complication. The deontic 'should' implies some kind of order or advice, which is not implicit in the already hyperbolized form. Similarly, the Saheeh translator preserves the simple present tense, but causes loss in the amount or quantity of the care intended.

Lawwam لوام:

The hyperbolic form occurs in the following verse 2 of Surah Al-Qiyamah:

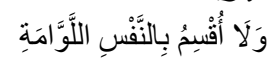

The translations are as follows:

$$
\text { Sah }
$$

And I swear by the reproaching soul [to the certainty of resurrection].

The problem here is an exegetical-cum-linguistic one. According to standard exegeses such as Tafsir Al-Qurtubi and Safawtu al Tafaseer, 'lawwamah' refers to the soul that blames its owner for their sins and for not effecting good deeds. Thus, it is reproaching and self-reproaching. However, it is also repetitively or even incessantly doing so. Thus, the Saheeh translator captures only part of the meaning by using the deverbal. Abdel-Haleem, likewise, captures only part of the meaning. A better solution would have been 'the ever-reproaching and self-blaming soul'.

\subsection{Partial (Sah), Flat (Ah)}

No examples are found in the corpus that can be subsumed under this category. This may stand in favour of AbdelHaleem's translation, for it further proves that his rendition is as faithful as he can.

\subsection{Partial (Sah), Comp (Ah):}

Qahhar قهار:

The hyperbolic form occurs in the following verse 16 of Surah Al-Ra?d:

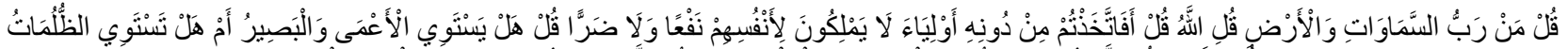

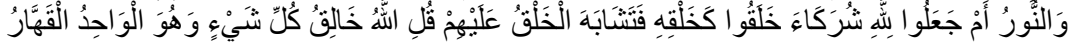

The translations are as follows:

\section{Sah}

Say, "Who is Lord of the heavens and earth?" Say, "Allah." Say, "Have you then taken besides Him allies not possessing [even] for themselves any benefit or any harm?" Say, "Is the blind equivalent to the seeing? Or is darkness equivalent to light? Or have they attributed to Allah partners who created like His creation so that the creation [of each] seemed similar to them?" Say, "Allah is the Creator of all things, and $\mathrm{He}$ is the One, the Prevailing."
$\mathrm{Ah}$

Say [Prophet], 'Who is Lord of the heavens and the earth?' Say, 'God.' Say, 'Why do you take protectors other than Him, who can neither benefit nor harm even themselves?' Say, 'Are the blind equal to those who can see? And are the depths of darkness equal to the light?' Have the partners they assign to God created anything like His creation so that their creation is indistinguishable from His? Say, 'God is the Creator of all things: He is the One, the All Compelling.'

The Saheeh translator uses the deverbal 'prevailing' preceded by the definite article. This partially conveys the meaning of continuity, but it ignores the aspect of omnipotence. Abdel-Haleem, on the other hand, manages to convey the full meaning by using the prefix 'all-', which is a standard morpheme in divine attributes. 
Tawwab تواب:

This hyperbolic form is repeated eight times in the following verses, which are followed by the two translations:

1. Al-Baqarah, verse 37:

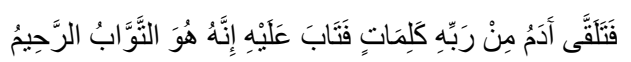

Sah

Then Adam received from his Lord [some] words, and He accepted his repentance. Indeed, it is He who is the Accepting of repentance, the Merciful.
$\mathrm{Ah}$

Then Adam received some words from his Lord and $\mathrm{He}$ accepted his repentance: $\mathrm{He}$ is the Ever Relenting, the Most Merciful.

\section{Al-Baqarah, verse 54:}

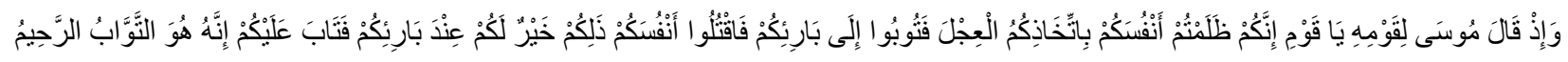

\section{Sah}

Our Lord, and make us Muslims [in submission] to You and from our descendants a Muslim nation [in submission] to You. And show us our rites [of Hajj and Omrah] and accept our repentance. Indeed, You are the Accepting of repentance, the Merciful.
$\mathrm{Ah}$

Moses said to his people, 'My people, you have wronged yourselves by worshipping the calf, so repent to your Maker and kill [the guilty among] you. That is the best you can do in the eyes of your Maker.' He accepted your repentance: $\mathrm{He}$ is the Ever Relenting and the Most Merciful.

3. Al-Baqarah, verse 128:

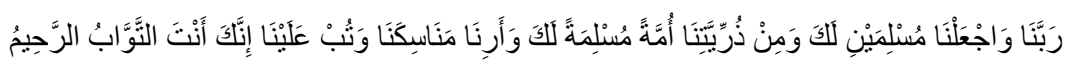

\section{Sah}

Except for those who repent and correct themselves and make evident [what they concealed]. Those - I will accept their repentance, and $\mathrm{I}$ am the Accepting of repentance, the Merciful.
$\mathrm{Ah}$

Our Lord, make us devoted to You; make our descendants into a community devoted to You. Show us how to worship and accept our repentance, for You are the Ever Relenting, the Most Merciful.

4. Al-Baqarah, verse 160:

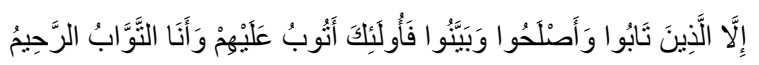

Sah

Except for those who repent and correct themselves and make evident [what they concealed]. Those - I will accept their repentance, and I am the Accepting of repentance, the Merciful.
$\mathrm{Ah}$

unless they repent, make amends, and declare the truth. I will certainly accept their repentance:

I am the Ever Relenting, the Most Merciful.

5. Al-Tawbah, verse 104:

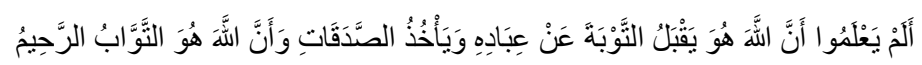

\section{Sah}

Do they not know that it is Allah who accepts repentance from His servants and receives charities and that it is Allah who is the Accepting of repentance, the Merciful?
$\mathrm{Ah}$

Do they not know that it is God Himself who accepts repentance from His servants and receives what is given freely for His sake? He is always ready to accept repentance, most merciful. 


\section{Al-Tawbah, verse 118}

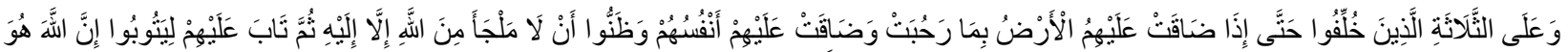

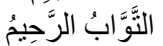

Sah

And [He also forgave] the three who were left alone [i.e., boycotted, and then regretted their error] to the point that the earth closed in on them in spite of its vastness and their souls confined [i.e., anguished] them and they were certain that there is no refuge from Allah except in Him. Then He turned to them so they could repent. Indeed, Allah is the Accepting of repentance, the Merciful.
$\mathrm{Ah}$

And to the three men who stayed behind: when the earth, for all its spaciousness, closed in around them, when their very souls closed in around them, when they realized that the only refuge from God was with Him, He turned to them in mercy in order for them to return [to Him]. God is the Ever Relenting, the Most Merciful.

7. Al-Nur, verse 10:

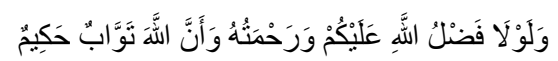

Sah

And if not for the favor of Allah upon you and His mercy... and because Allah is Accepting of repentance and Wise.
$\mathrm{Ah}$

If it were not for God's bounty and mercy towards you, if it were not that God accepts repentance and is wise ....!

\section{Al- Hujurat, verse 12 :}

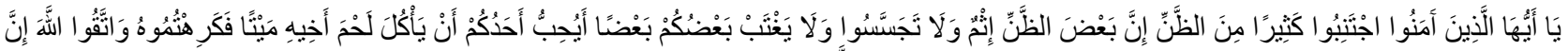

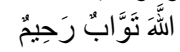

\section{Sah}

O you who have believed, avoid much [negative] assumption. Indeed, some assumption is sin. And do not spy or backbite each other. Would one of you like to eat the flesh of his brother when dead? You would detest it. And fear Allah; indeed, Allah is Accepting of repentance and Merciful.
$\mathrm{Ah}$

Believers, avoid making too many assumptions- some assumptions are sinful- and do not spy on one another or speak ill of people behind their backs: would any of you like to eat the flesh of your dead brother? No, you would hate it. So be mindful of God: God is ever relenting, most merciful.

In the aggregate, the Saheeh translator remains consistent: the epithet 'the Accepting of repentance' is preserved for 'tawwab'. Although consistency is a sign of careful editing, it reveals that the effort needed for checking the intended meaning of the hyperbole is lost in all these examples. This detracts from the quality of the translation. In contrast, Abdel-Haleem alternates between 'Ever Relenting' and 'always ready to accept repentance', the latter being a paraphrase. He succeeds in capturing the full meaning by means of adding 'ever' to the deverbal, and by using the adverb 'always'.

\section{Discussion}

Based on the above analyses, it is evident that the two translators have, to some extent, diverged in their attempt at rendering the hyperbolic form modeled on the pattern 'fa??al' in the present study. The Saheeh translator has tended to flatten around 29 of the examples examined; and partially conveyed the sense intended in six other examples. The net result is that the Saheeh translation is left with only five examples accurately (or 'completely') rendered.

Abdel-Haleem's translation stands in clear opposition to the Saheeh one. Abdel-Haleem has flattened only 18 examples, and partially conveyed the implied meaning in 16 other examples. His accurate renditions amount to 18 instances. Thus, he strikes some balance between partially and completely rendered examples. In a sense, these figures reveal that Abdel-Haleem has made much effort in translating the 'fa??al' hyperbolic forms examined in the present corpus. 
As for the use of translation strategies, the Saheeh translator has applied morphological shifting in many examples: this may be attributed to copying the Arabic pattern without giving due thought to the other strategies that can be used. The use of syntactic transposition is rather sporadic, being confined to partial and complete renditions. This may be one reason why the flattened outputs are widely noticed in her translation. Abdel-Haleem's translation, in contrast, exhibits a considerable amount of syntactic transposition, coupled with paraphrasing. This may be one reason why his accurately translated outputs occupy quite a good amount.

It can be concluded that the 'fa??al' hyperbolic form has shown how Qur'an translators approach such a demanding pattern. The test of accuracy as administered here is to give a clear picture of the need to pay particular attention to hyperboles of the form examined and other ones not analyzed here for limitations of space. It seems that Qur'an translators are in need of heeding such nuances of meaning when conveying the eternal word of God.

\section{References}

Primary Sauces:

Arabic Primary Sources:

$$
\text { القر آن الكريم. }
$$

English Primary Sources:

Abdel-Haleem, M.A.S. (2004) The Qur'an :a new translation. Cambridge: CUP.

Saheeh International (1997) The Quran, Arabic text with corresponding English meaning. Riyadh: Abulqasim Publishing House.

Secondary Sources:

Arabic Secondary Sources:

$$
\begin{aligned}
& \text { ابن جني، أبو عثمان المازني المصري، الخصائص، تحقيق محمد علي النجار(1952) ، مصر، مطبعة دار الكتب المصر ية . }
\end{aligned}
$$

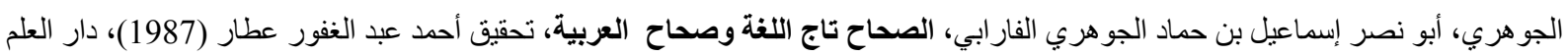

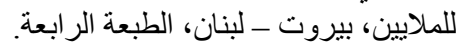

$$
\begin{aligned}
& \text { الصابوني ، محمد علي، صفوة التفاسير(1997 ) عدد الأجزاء } 3 \text { ، دار الصابوني للطباعة والنشر والتوزيع، القاهرة. }
\end{aligned}
$$

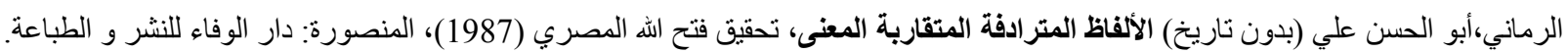

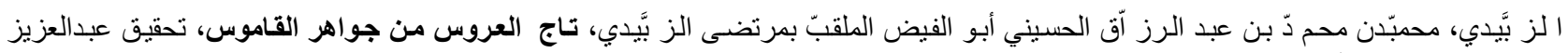

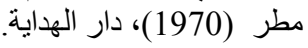

$$
\begin{aligned}
& \text { الزمخشري، أبو القاسم جار الله محمود بن عمر :الكثـف عن حقائق التنزيل وعيون الأقاويل في وجوه التأويل، لبنان - بيروت، دار المعرفة للطباعة } \\
& \text { والنشر. } \\
& \text { العسكري، أبو هلال (بدون تاريخ) الفروق اللغوية، تحقيق و تعليق محمد إبر اهيم سليم (1997)، القاهرة: دار العلم و الثقافة. }
\end{aligned}
$$

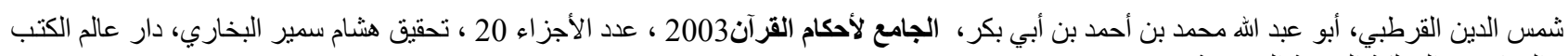

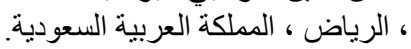

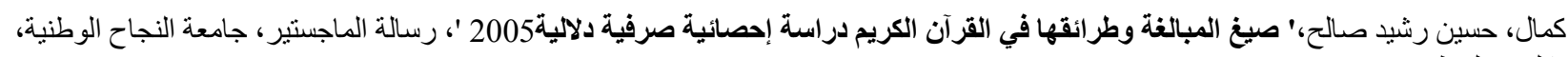

$$
\begin{aligned}
& \text { نابلس، فلسطين. } \\
& \text { مجمع اللغة العربية، المعجم الوسيط (2003 ) ، مكتبة الثروق الدولية، الطبعة الرابعة، مصر ـالقاهرة }
\end{aligned}
$$

\section{English Secondary Sources:}

Arabic Gems (January, 2007) http://www.arabicgems.co.uk/

Drew, P. \& Holt, E. (1998). Figures of Speech: Figurative Expressions and the Management of Topic Transition in Conversation. Language in Society 27, 495-522.

Dung, T. T. (2011) A Study on syntactic, semantic and pragmatic features of exaggeration in English and Vietnamese. M.A. Thesis in the English Language. [Online] Available:

http://webcache.googleusercontent.com/search?q=cache:U8aHcEvubx8J:tailieuso.udn.vn/bitstream/TTHL_125/1040/2/ Summary.pdf $+\& c d=56 \& h l=e n \& c t=c \operatorname{lnk} \& g l=e g($ September 20, 2013).

Fazel, A. A. (2013) Problems and Strategies in English Translation of Quranic Divine Names. International Journal of Linguistics, Vol. 5, No. 1, 128-142.

Gibbs, R. W. (2000).Irony in Talk among Friends. Metaphor and Symbolic Activity 15, 5-27.

Khaleel, M. (2005 Assessing English Translations of the Qur'an. Middle East Quarterly, Spring, 58-71.

McCarthy, M., \& Carter, R. (2004). There's Millions of Them: Hyperbole in Everyday Conversation. Journal of Pragmatics, 36 (2), 149-184. 
Mora, C. L. (2004). At the Risk of Exaggerating: How Do Listeners React to Hyperbole? Anglogermanica ,2. [Online] Available: http://anglogermanica.uv.es:8080/Journal/Viewer.aspx?Year=2003-04andID=cano.pdf (September 5, 2013).

Random house Webster's unabridged dictionary, 2nd Ed. (2009). CD-Rom.

Sert, O. (2008) An Interactive Analysis of Hyperboles in a British TV Series: Implications for EFL Classes. Arecls, Vol.5, 1-28.

Shah, S. M. (n.d.) A Critical Study of Abdel Haleem's New Translation of the Holy Qur'an. Retrieved [Online] Available: http://pu.edu.pk/images/journal/uoc/PDF-FILES/(1)\%20Dr.\%20Sultan\%20Shah.pdf (September 5, 2013).

Van Dijk, T.A., (1995). Discourse, Opinions and Ideologies. Current Issues in Language and Society, 2 (2), $115-145$.

\section{Notes}

${ }^{\mathrm{i}} \mathrm{http}: / /$ www.saheehinternational.com/ (accessed 23 November 2013).

${ }^{\text {ii }}$ Although occurring in the same verse, the hyperbolic form 'mashaa' (i.e. habitually walking) is accurately translated. This is why it is not included in the above discussion.

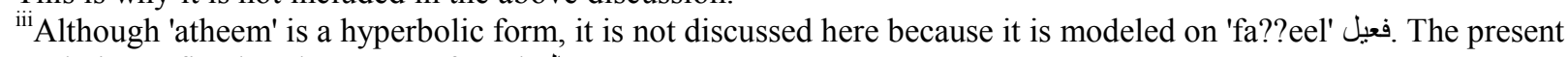
study is confined to the pattern 'fa??al' فعال.

\section{Appendix}

The Transliteration Code

\begin{tabular}{|c|c|}
\hline Arabic Letter & Code \\
\hline$\&$ & 1 \\
\hline 1 & $\mathrm{a}$ \\
\hline ب & $\mathrm{b}$ \\
\hline$ت$ & $\underline{\mathrm{t}}$ \\
\hline$\dot{H}$ & th \\
\hline ج & $\mathrm{j}$ \\
\hline$\tau$ & $\underline{\mathrm{h}}$ \\
\hline$\dot{\tau}$ & $\mathrm{kh}$ \\
\hline د & $\underline{\mathrm{d}}$ \\
\hline$\dot{j}$ & $\underline{\mathrm{dh}}$ \\
\hline$J$ & $\mathrm{r}$ \\
\hline$j$ & $\mathrm{z}$ \\
\hline س & $\mathrm{S}$ \\
\hline ش & $\underline{\mathrm{sh}}$ \\
\hline ص & $\underline{\mathrm{S}}$ \\
\hline ض ض & $\underline{\mathrm{d}}$ \\
\hline$b$ & $\underline{\mathrm{t}}$ \\
\hline ظ & $\underline{\underline{z}}$ \\
\hline$\varepsilon$ & $\underline{S}$ \\
\hline$\dot{\varepsilon}$ & gh \\
\hline ف & $\mathrm{f}$ \\
\hline ق & $\mathrm{q}$ \\
\hline ك5 & $\mathrm{k}$ \\
\hline J & 1 \\
\hline 5 & $\mathrm{~m}$ \\
\hline$\dot{ن}$ & $\mathrm{n}$ \\
\hline 0 & $\mathrm{~h}$ \\
\hline 9 & $\mathrm{~W}$ \\
\hline يُ & $\mathrm{y}$ \\
\hline$\ddot{i}$ & $\mathrm{a}$ \\
\hline$\ddot{0}$ & ah, at \\
\hline
\end{tabular}

